\title{
Revisiting moral panics
}

\author{
Viviene Cree, Gary Clapton and Mark Smith (Eds), 2016 \\ Policy Press, Bristol, England. \\ ISBN 978-1-4473-2186, pp.280, paperback, NZD43.00
}

I grabbed onto Cohen's Folk Devils and Moral Panics when it came out in 1972 (Cohen, 2002). I was studying then, but soon found myself teaching deviance and normality to sociology students. They were familiar with Becker (Outsiders, 1963). There was an appetite for material that drew on the experience of student life. Outsiders spoke of becoming a marijuana user, listening to jazz. You could gaze into the notion of hip or life as sub-culture. Music, politics and identity linked to emerging social mobility, diversity and creativity.

Cohen re-set the story in the UK with mods and rockers. The possibility of a critical narrative was flipping. The object of curiosity was less on us as an emergent threat and more on the way conventional society was so reactive, so keen to repress, to panic! We chilled with some incredulity as Cohen laid out an analysis of what was being done, why the establishment was so exercised by our existence. He wrote of social coercion employing method, data and stories gathered from our lives - from the street, the events in urban landscapes in which we roamed and made claim to public places. Cohen remarkably realised how these sites were the opportunity for the establishment to pick out a devil and instil panic in their comfortable, indignant allies. Establishment figures speaking through an establishment media were usefully and methodically depicted by Cohen as massing their armoury against our emergent hopes and aspirations. Our identity was a threat. They twisted detail, cultivated stereotypes and fanciful 'what ifs' to generate panic that justified more bricks in the wall; more social control.
Surely this was the exposure that could help cool to prevail.

There was an account in Cohen's material of an outrage, when a lad up in court was fined an outrageous amount - \$50 maybe - by the pontificating judge. The lad brandished back, 'I'll pay it with a cheque!' The papers erupted. They did not get sarcasm. How far could draconian go before it was recognised as facile. Youth were not the problem. How we 'did' society was the issue. How our elders governed, how establishment media made news, how commentary ostracised some and gloried others, how an elite remained so arbitrary and smug, could all be evidenced; maybe the focus could move back to how might we create effective social policy or social cohesion.

So this edited book Revisiting Moral Panics (2016) invites us first to reflect how things have developed since then. Edited by social work academics, following a series of seminars in the United Kingdom (Moral Panics blog, n.d.), the text brings together a global range of authors to consider continuing accounts of the folk-devil/ panic/control dynamic. Calling out a devil, a community to castigate still targets many; women, children, troubled, feral, Maori, Welsh, Roma, chavs, the dying, digital frontiers - from Italy, Holland, Aotearoa New Zealand, the United Kingdom and we get them all in this volume. The collection reminds us that communities are still targeted and sadly that our efforts to modify a dominant practice of oppression and marginalisation have not diminished. There is a hint here that whatever we have been doing with this analysis and 
knowledge has not shifted the pattern. The scope for the establishment to play these cards has not been extinguished. As the example here show the strategy is endemic and widespread. Conventions of power continue to be abusive and people in need are more likely to be harassed than supported. Practitioners located in networks of services and support need to be capable of calling out the tactic whereby repression puts denial and obfuscation ahead of any insight into how things may be bad, unjust and indeed, indicative of a case for reform.

There is a very well worked out pattern in the volume where commentary and extension of the theory is woven with the stories from the front line. Many times we can imagine the phenomenon explored here being the ' $6 \mathrm{pm}$ news' where issues and constructs are reduced to sound bites. We can grasp how news becomes sport as factions try to score. Who can make the slam-dunk and send the other team reeling? The editors, by their selection and organisation of the text, were keen to remember those early scholars who were in their time relevant, heroic and insightful. They are useful chapters on the background and future of panic modalities although I would like to go see the suggestions go further than reminding front line practitioners to ask the critical questions. It is clear that private troubles demand public mobilisation; professional practice must be connected to civic action.

The editors' own chapters where they add in their appraisals are a tribute to good sociology and research based advocacy. The material draws us into reflection on how practice might shift intractable social realities. These patterns of denial and obfuscation repeat and linger, forming the new notion of a wicked problem.

The editors want to speak directly to social workers however they maybe placed as practitioners and activists, who in the time and in the constancy of their work need to be clever to restore agency to people's lives. Because that will never be sufficient, practitioners must then rise from supporting those who feel the oppression, to speaking to those gatekeepers in the powerful world, preoccupied with holding off the feeling to care, bereft of ideas and maybe even concern or care.

The largest portion of the book is devoted to a fascinating range of examples and case histories. Authors from all parts of the globe report on all manner of devils and panics. The chapter on "feral families" in New Zealand by Liz Beddoe sits alongside several chapters where conventions about mothering (Sally Brown) child protection (Ian Butler) "lost childhood" (Kay Tisdall) each offer short and helpful accounts of the way conventional power-holders will demand a return to simplistic family orthodoxy, never to imagine what it takes to provide support and lift struggling folk out of forsaken circumstances. Further chapters recognise the tendency to point the finger rather than offer the hand. In another framing of power and inertia there are chapters which retell how institutions of trust and sanctuary can be revealed as abusive and unsafe but it does not follow that reform is quick. First there is resistance, possible denial and then so much commotion in the name of inquiry. Chapters by Mannay, le Grand and several others are useful demonstrating how applicable and plentiful the scholarship Cohen inspired has become. Most authors here are academics, not all in social work, using their research as a catalyst for action. There are practitioners here too talking about the situations they confronted in their work. There is willingness in this publication to motivate practitioners to press on. To be insightful requires powers of observation and places to present that content. It means taking informed content to audiences in communities, causes and sites of influence. It is valuable to share knowledge and rebut the obvious agenda offered in mainstream media, by authorities, by the pontificators and those who are quick to defend the status 
quo. We can use the notions of the public domain and the public interest to mobilise equity in the narratives that get noticed. Rebuttal is a step along the way, but rebuilding inclusive communities is more demonstrative, building a robust civic habitat.

This text aims to empower practitioners to do a better job for and with their communities and citizens. Herein are valuable and wide ranging chapters about panics and the fallacy that a shrill call will capture any initiative and negate what really needs to be addressed. The support these chapters get from the editorial contributions which pay their respects to the moral panic pioneers, creates a compendium, archaeology of ways we can be resistant to those who want to make the agenda their cheap shots and draconian measures. Much of the tool kit of good practice lies in the concepts and analysis that is used to inform and motivate effective engagement. This text is timely and we know the time is now.

\section{References}

Becker, H. (1963). Outsiders: Studies in the sociology of deviance. London: The Free Press.

Cohen, S. (2002). Folk devils and moral panics. ( $3^{\text {rd }}$ ed.). London: Routledge.

Moral Panics Blog (n.d.). Revisiting moral panics: A critical examination of $21^{\text {st }}$ century social issues and anxieties. Seminar Series Blog. Retrieved 14 October from: https://moralpanicseminarseries.wordpress.com/

Reviewed by Phil Harington University of Auckland, New Zealand 